\title{
伸筋支帯を用いた手関節 形成術
}

\author{
大分医科大学整形外科 \\ 鳥 巣 岳 彦・真 角 昭 吾
}

\section{Arthroplasty of the Rheumatoid Wrist with Extensor Retinaculum}

by

\author{
T. Torisu and S. Masumi \\ Department of Orthopedic Surgery, Medical \\ College of Oita, Oita, Japan
}

\begin{abstract}
The effect on synovectomy and débridement with resection of distal end of the ulna is generally accepted. The one problem is the osseous ankylosis of the radiocarpal joint. The ankylosis of the radiocarpal joint often develops after the operation, when erosion of the articular cartilage in the radiocarpal joint exsists at the operation. But unfortunately, this finding has been neglected, presumably because the restoration of stability far overweighed any minor functional impairment brought about by lack of motion after the operation. We believe, if possible, the existence of pain free motion of the wrist is the more beneficial and functional in the rheumatoid patient.

A technique of partial arthroplasty without ulnar head resection in the rheumatoid wrist was recommented. A flap of the extensor retinaculum was used as interposition material in the radiocarpal joint for covering the eroded articular surface of the radius and ulna. It must be stressed that this procedure is so useful as to stabilize the ulnar head, prevent volar subluxation of the carpus on the radius and prevent the postopera tive osseous ankyosis of radiocarpal joint.

In the severely destructed wrist with collapse on the ulnar and volar side of the radius, radial head prosthesis or total wrist replacement was rather recommended as implant arthroplasty.

The indication of the arthroplasty was also discussed in connection with that of the arthrodesis in the rheumatoid wrist.
\end{abstract}

人工物を用いない関節形成術として， RA の手関節 に用いられる手術法は，手根骨の中枢列を切除する proximal row resection, 手根骨の掌側脱臼を矯正 する目的で棚状に橈骨遠位端を形成する palmar shelf arthroplasty, 尺骨頭之橈骨遠位端を切除し背 側手根靯帯で橈骨切除端を被う Allende's arthroplasty などが報告されている，私にはその経験がない がステロイド内服中の骨萎縮が強い RA では，断端 の吸収の程度が予測出来ず不安定な動摇関節を生じ易 いととも事実である．また再強直が起るととも問題で ある.

一方関節破壊の少ない RA の手関節に対し，除痛 効果之機能改善を期待して行なわれる, いわゆる滑膜
切除術の一般的評価は良好である. 非苛重関節である 手関節に於いても, 手術時の関節軟骨の破壊の程度が 機能的あるいは器質的な予後に直接結びつくので, 炎 症滑膜のみを切除する synovectomy（滑膜切除術）

と synovectomy and débridement (滑膜切除並び にデブリードマン）という用語とは区別して用いなけ ればならない，特にレ線像に関しては, 手関節に於い てすら炎症滑膜を切除しても関節破壊の進行をくい止 める事は困難であり，特にデブリードマンを併せ行な った症例において関節破壊の進行は必発である.

写真 1-A， B は滑膜切除とデブリードマンが行な われた症例の術前と術後のレ線像であるが, 術後に橈 骨之手根骨中枢列之の間に骨性強直が生じている. 手 
術によって疼痛は全くなくなり，回内回外運動む良好 で, 握力も增加したのであるが, 術前存在した 40 度 近くの手関節可動域は殆んど消失してしまった．乙の 症例の術中写真は写真 $1-\mathrm{C}$ に示す通りであり, 術前 のレ線像でも分かる通り, 月状骨之橈骨との間にリウ マチ性肉芽の浸閪による軟骨面のエロジオンが存在し た．との部分をほぼ完全に近くデブリードマンを行な

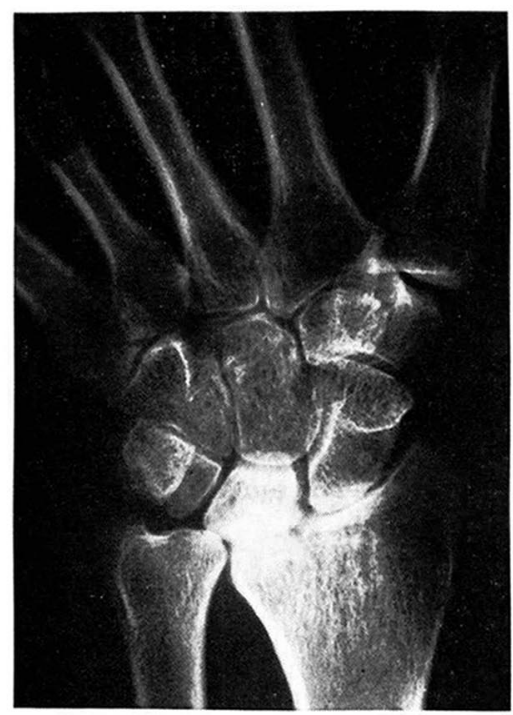

写真 1-A 術 前

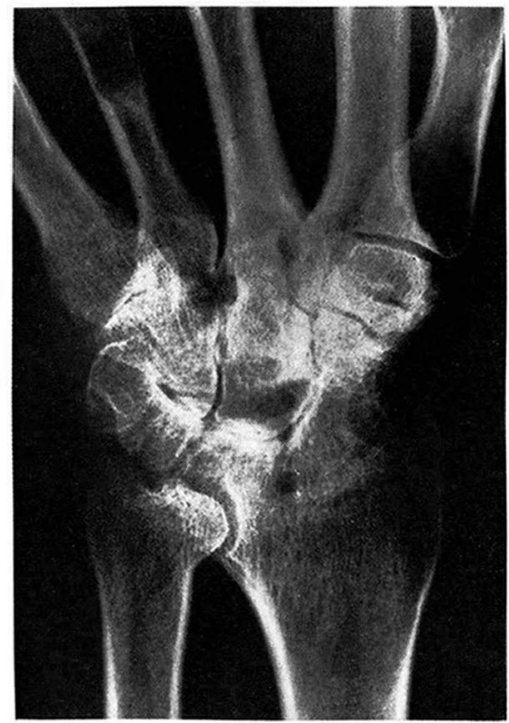

写真 1-B 術後 2 年目
ったために術後強直を来たしたものと思われる．との 様に橈骨関節面にエロジオンを有する症例の術 後に は，必ず骨性強直が生じ可動域が著しく減少すること より，私は 7 年前より背側手根鞄帯を radiocarpal joint に挿入し，関節形成術を行なっているのでその 手術方法を紹介する.

皮㧂切開はゆるやかな $\mathrm{S}$ 字状切開を用いる. Lister 結節の部で伸筋支帯を縦切開し, 弁状に左右に剝離, 反転する．その際增殖した伸筋腱群の周囲の腱鞘性滑 膜は丁寧に除去する．伸筋腱を両側に分けて手関節を だしたあよ，まず尺骨頭を被る膨隆した滑膜を関節包
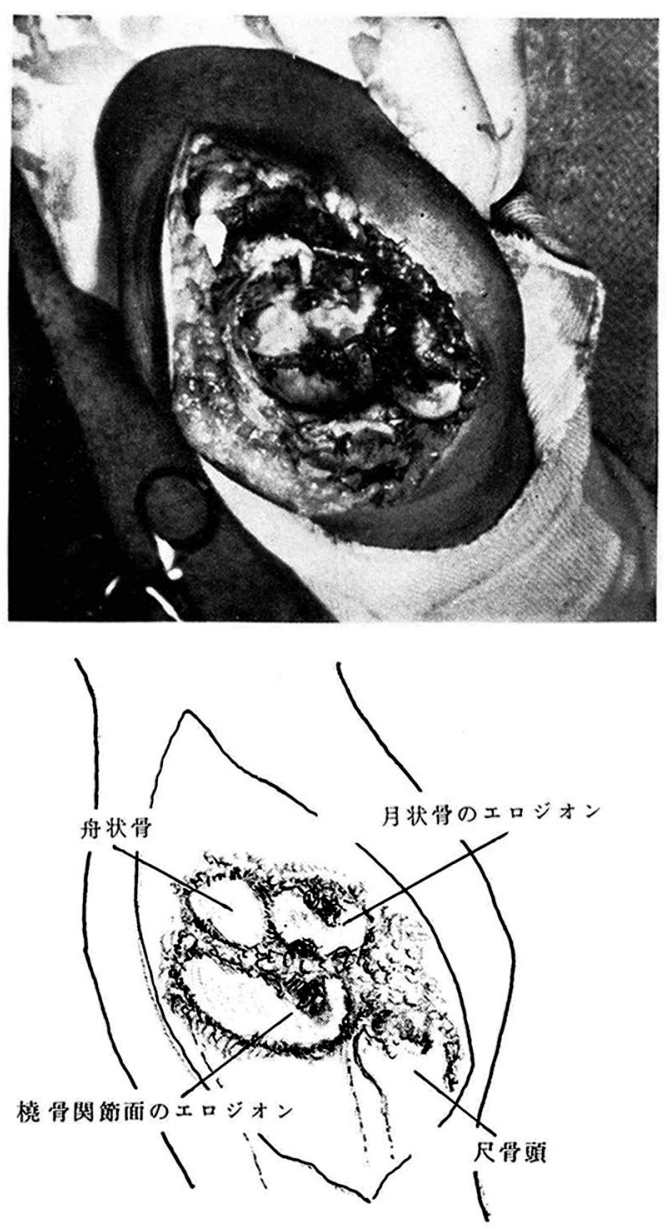

写真1-C 術中写真.

月状骨と樈骨との間の関節㳄骨の破壊が著るし い. との様な症例の所謂滑膜切除後には必ず月状

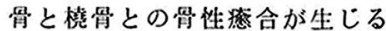


とともに一塊として切除する.すでに橈尺関節の勒帯 は断裂むしくは弛緩しているので，背側より充分に橈 尺関節のデブリードマンを行なうことが可能である.

次いで radiocarpal の背側にある增殖滑膜を切除 し，手関節を過掌屈位に保持する，そこで橈骨関節面 周辺の pannus を切除する. 掌側の関節包の増殖滑 膜も切除する．橈骨の掌側尺側よりに梁く骨䯣内に侵 入したリウマチ性肉芽がある場合には，乙れも搔爬し 除去する.

尺骨茎状突起に付着した尺側側副靶帯や，disc は可 及的に残すが変性が著しい場合には切除してもよい. 次いで midcarpal の滑膜を切除するが手根骨を横に 繋ぐ靶帯は温存する.
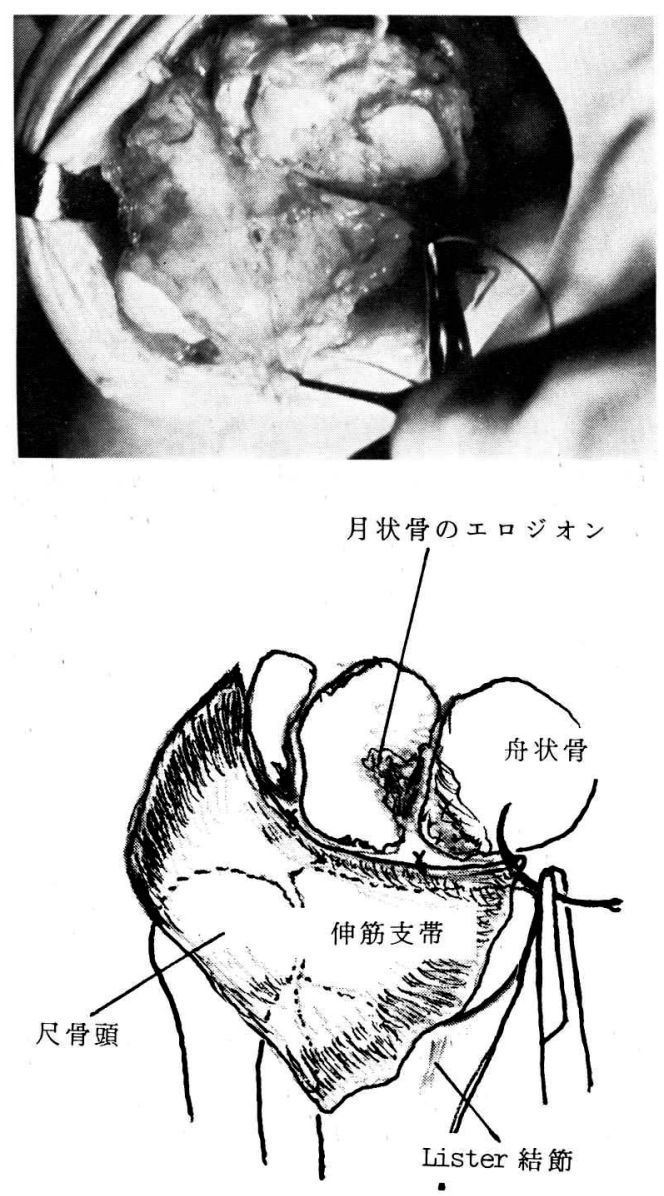

写真 2

伸筋支带で尺骨頭，橈骨関節面を被う。掌側関 節包にまず縫合
一応炎症滑膜の切除が終ったところで，反軽してい た伸筋支帯を伸筋腱の掌側に移し，更に radiocarpal joint に挿入し橈骨遠位端の関節面を被う様にして掌 側の関節包に縫合する (写真 2 ). 次いで手関節をを正 中位に戻したあと前腕中間位で尺骨頭をおさえ込む様 にして緊張をかけて背側手根䩲帯を Lister 結節に固 定縫合する (写真 3 ). その後は通常の手術と同じで ある.

この手術の特長は,
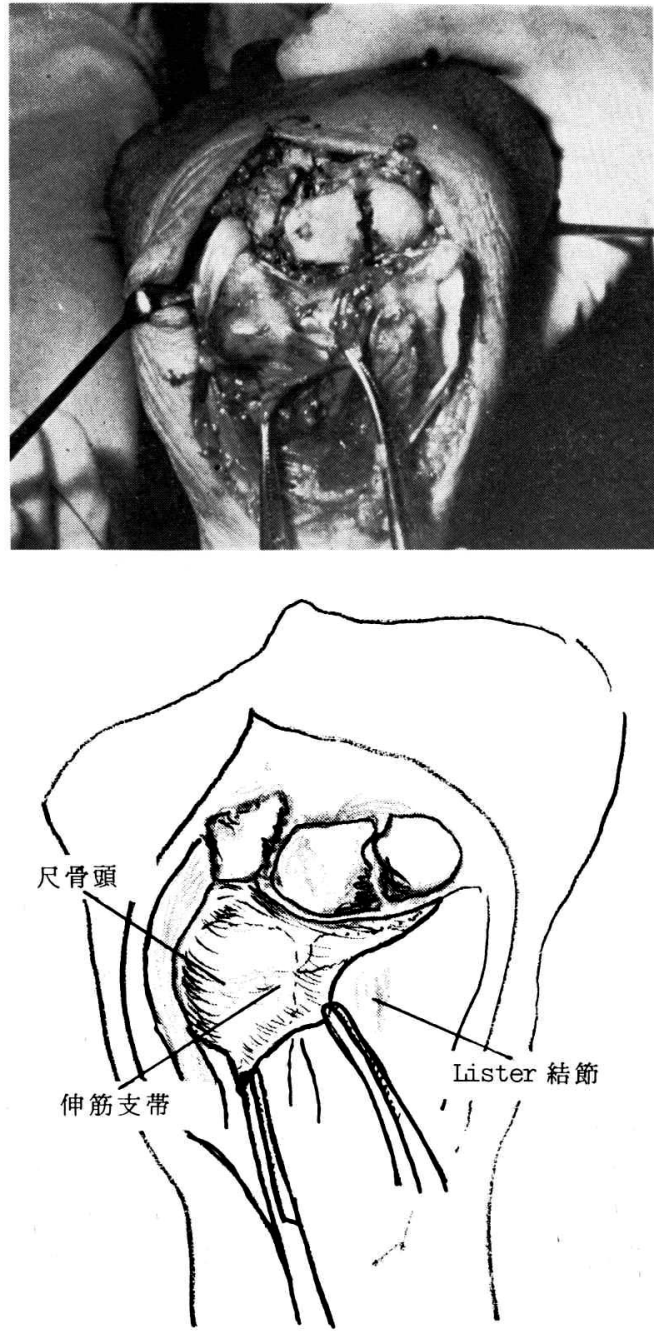

写真 3

伸筋支带を緊張をかけて Lister 結節に縫合し 尺骨頭をおさえ込む 
1） 尺骨頭は切除しないので尺側に偏位した手根骨 を尺骨頭を支持することが出来る（写真 $6-\mathrm{B}$ ).

2） 尺骨頭は伸節支帯で緊張をかけておさえ込む様 に原位置に個定するので尺骨頭は術後も脱臼を起さな い．また摩滅した尺骨頭は trimming したあと伸筋 支帯で被われるので腱の断裂は予防できる.

3） 尺側手根伸展腱の付着部が背側にもちあがって 位置するようになり（写真 4，5)，乙れも尺骨頭を おさえ込むととになり背側脱臼の予防に役立つ.

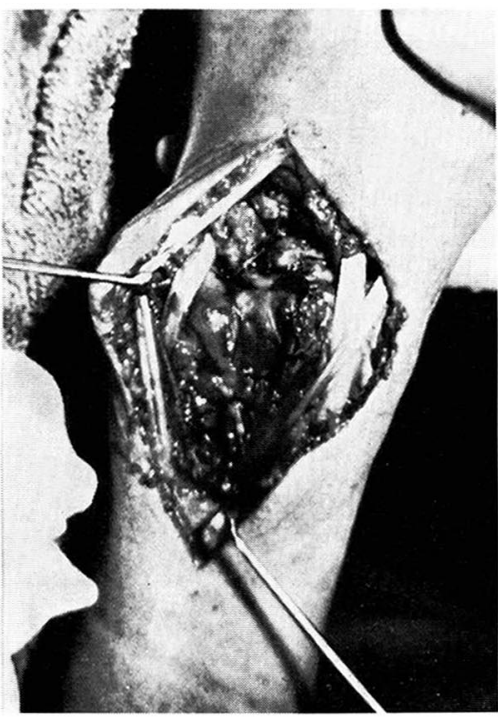

真写 4

尺例手根伸筋が伸筋支带に持ち上 ケられて背侧に位置するようになる

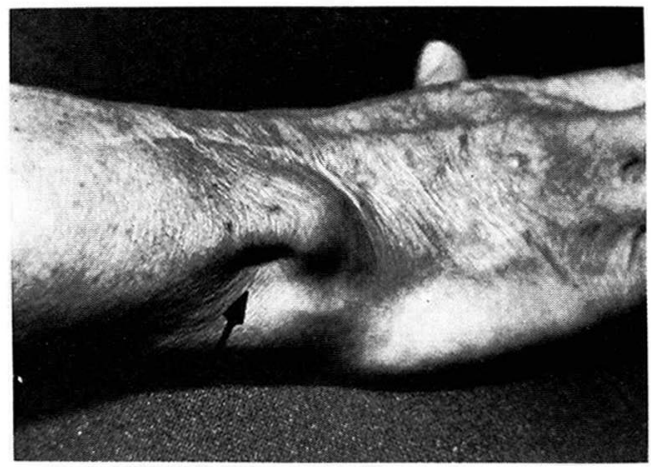

写真 5

術後 1 年後の状態であるが尺側手根伸筋が尺骨 頭をおさえ込み尺骨頭の背侧脱目の予防に役立っ ている
4）橈骨遠位端関節面と尺骨頭を伸筋支帯で被うた め, これによりエロジオンのある橈骨と月状骨との間 に骨性瘉合が起らず，手関節の掌背届がある程度維持 出来る. 術後のレ線像でも関節裂隙を確認出来る（写 真 $6-\mathrm{A}, \mathrm{B}$ ).

5）伸筇支帯を伸筋腱の掌側を通し， radiocarpal の掌側関節包に綎合固定することにより，手根骨の掌 側脱且が防止出来る.

などである.

後療法は術後, 肘関節 90 度屈曲位, 前腕回 外位, 手関節は掌背屈中間位にて 5 日間ギプスシーネで固定 する．その間患肢挙上，指の屈伸による muscle pumping exercises を行ない浮腫予防, 筋力增強に つとめる. 5 日目にはギプスシーネをはずし时関節の 届伸前腕の回内回外運動を許可する．腱断裂を伴なう 症例では腱移行を併せ行なったあとギプスシーネと共 に弾力副子を用いている. 弾力副子は 3 週間後に除去 する.

以上 radiocarpal の変化が中等度の症例では 極め て有用な伸筋支帯を利用した関節形成術も，橈骨遠位 端の関節面が掌尺側に破壊し陥凹した症例などには適

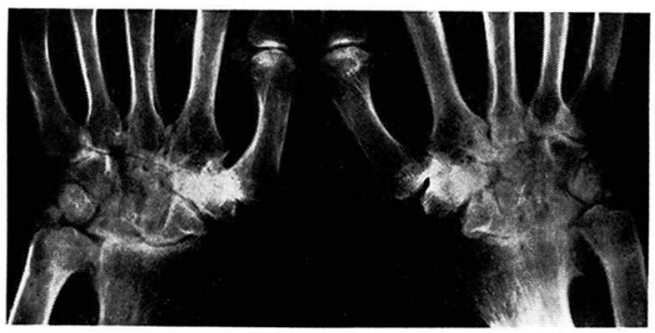

写真 6-A

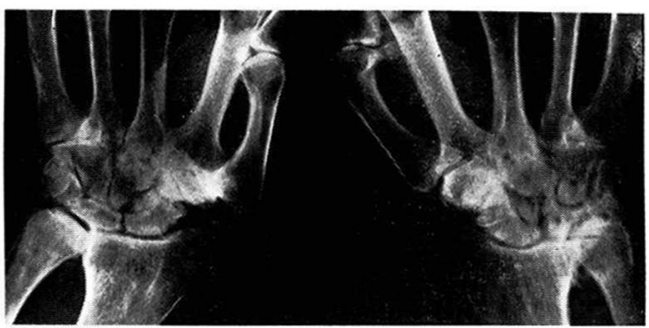

写真 6-B

左側は手関節の手術を行ない，右側はそのまま 経過を観察した症例．右側の変化は進行している. 左倒は伸筋支帯を挿入した尺骨頭と月状骨，筧骨 と月状骨・舟状骨との間に関節裂隙が確認出来る。 
応外である．橈骨面を伸筋支帯で被っても傾きの関係 で支持性の獲得が難しい．また関節破壊の進行した症 例では背側手根勒帯そのものが菲薄化し摩滅し破たん しており，関節面を被ったり，尺骨頭を固定するに充 分に強靶ではないからである。したがってその様な症 例では他の関節形成術が適応となる．手関節は手指の 功緻運動に際し充分な支持性が不可欠であり，その観 点より人工関節置換術は手関節固定術との関連に於い て merit, demerit がたえず問題になる.

慢性関節リウマチの場合, 整容動作や排便動作等の $\mathrm{ADL}$ 上問題になるのは，近位の関節でごれだけ手関 節の代償が着能かというととである．その点 R A の場 合関節破壊が両側性であり，多発性であるところに固 定術ならぬ関節形成術の存在意義があると思われる.

(ここに呈示した症例の全ては著者が九州労災病院 整形外科在職中に治療した症例であることをお断りい たします.）

\section{文献}

1) Eiken, O. et al.: Assessment of Surgery of the Rheumatoid Wrist. Scand. J. Plast. Reconstr. Surg., 9: 207, 1975.

2) Jackson, I. T. et al.: Ulnar Head Resection in Rheumatoid Arthritis. The Hand, 6: 172, 1974.

3) Linscheid, R. L. et al.: Rheumatoid Arthritis of the Wrist. Orthopedic Clinics of North America, 2: 649, 1971.

4）森益太ほか：リウマチの手の手術経験とその問 題点：整形外科, 23: 1119, 1972.

5）諸富此文ほか：Rheumatoid Wrist の Synovectomyに関する問題点について：整形外科, 23 : $1124,1972$.

6) Straub, L. R. et al.: The Wrist in Rheumatoid Arthritis. J. Bone Joint Surg., 51A : 1, 1969.

7）鳥巢岳彦ほか：慢性関節リウマチの手関節に対 するいわゆる滑膜切除術について一特に遠位橈尺 関節の処置について：整形外科，24：1256, 1973.

8）鳥宩岳彦ほか：慢性関節リウマチの手関節に対 する動態撮影法の検討：整形外科, 25：1358, 1974. 